Reason and Democracy 



\section{Reason and Democracy}

Thomas A. Spragens, Jr.

Duke University Press - Durbam and London 1990 
(C) r 990 Duke University Press

Printed in the United States of America on acid-free paper $\infty$

Library of Congress Cataloging-in-Publication Data appear on the last printed page of this book. 
To

T. A. S. and C. S. S.

with thanks

- 
